\section{Assessing the OTA}

Congress's three-year-old Office Technology Assessment (OTA) has come under sharp, and potentially damaging, criticism from another Congressional committee and from the former chairman of its own advisory council. Both have argued that it has failed to live up to expectations and that there is still no clear understanding of its role and function. Colin Norman reports from Washington.

Established in 1972 by an Act of Congress, OTA is meant to furnish Congress with advice and analysis concerning scientific and technological issues. Its mission is frequently described as providing an early warning system on such matters. But its chief problem, which lies at the root of much of the criticism, is that on the one hand it is expected to study long-term issues, while on the other it is supposed to help Congress, which is more concerned with yearly budgets and twoyearly elections.

OTA studies and reports on matters referred to it by other committees of Congress, and it also generates some studies itself. Its operations are managed by a Director, Emilio Q. Daddario, a former Congressman who wrote the original legislation which led to OTA's establishment, and its policy is provided by a boand consisting of six Senators and six Congressmen. In addition, an advisory council, whose members are drawn from industry and academia, provides advice on OTA's operations.

The first criticism of OTA's operations surfaced in the office's recentlypublished annual report, which contained a letter from Harold Brown, President of Caltech, resigning as chairman of OTA's advisory council, and a response from Representative Olin Teague, chairman of the office's governing board.

Written last December, the letter begins with some words of praise for a few OTA studies, but criticises the fact that the office has taken on too many trivial tasks and asserts that "few of us on the council, I believe, would say that we are satisfied with what has been accomplished, compared with what we hoped for and still believe possible". Brown suggests in particular that OTA has been concentrating too much on immediate problems: "inevitably there are strong pressures on the Congress as well as on the Executive Branch to concentrate on immediate problems. Certainly those problems must be faced as they arise. But there needs to be a balancing effort within the Congress to foresee problems of the medium and even the long term future"

Less gentle criticism has come from

\section{NSF budget goes to conference}

Hopes for at least a modest increase in funds for basic research in the United States have been unexpectedly revived by the Senate. After intensive lobbying from scientific and higher education organisations, the Senate last week restored most of the money which the House of Representatives had slashed from the budget of the National Science Foundation (NSF), and the matter must now be decided in a conference committee consisting of members from each body. It's a fair bet that NSF will end up with a small increase, though not as great as the $20 \%$ boost proposed by the Ford Administration.

President Ford's budget request for NSF for the fiscal year which begins on October 1 was designed to offset the effects of inflation, which has eaten deeply into support for basic research over the past few years. But the House slashed nearly $\$ 60$ million from NSF's budget, giving an obscure Congressional body, known as the House Commission on Information and Facilities, chaired by Representative Jack Brooks of Texas. On the basis of an 8-month study, the commission last week issued a report which concludes that "OTA remains substantially short of reaching levels of performance reasonably expected of an information resource of its size and cost and access to expertise". The report, in short, suggested that OTA has been beset by operational problems and by lack of a clear definition of its functions.

The report states that the Commission found confusion among OTA's staff, council and board, and between OTA and some Congressional committees, over the office's role and responsibilities. It suggests, therefore, that OTA's statutory authority should be reviewed, and a clear definition of technology assessment should be drawn up, presumably so that OTA's territory is staked out and so that there's no overlap of its functions with those of the Congressional Research Service or the General Accounting Office. The report goes on to state, however, that so far there has been no such overlap.

More specifically, the report expresses reservations about the fact that OTA has been performing a growing share of its studies itself, rather than having them done by outside contractors, and suggests that OTA should have a firmer policy on which kinds of studies should be performed in-house. That criticism conflicts, however, with a comment made by Brown in his letter. Listing some "substantial advances" made by OTA, Brown notes that "an initial tendency to think almost solely in terms of contracted studies has been succeeded by a more balanced procedure involving advisory panels, contracted studies, and some (as yet rather little) in-house assessment work"

But perhaps the Commission's most biting criticism concerns OTA's administrative structure. "Organisationally", it says, "OTA lacks the minimum of orderly structure", and it suggests that OTA should begin immediately, if necessary with the help of management consultants, to put itself in order.

Finally, both the Commission and Brown criticise the poor relations which have developed between OTA and its advisory council. "At one time or another", Brown states, "most Council members have expressed frustration about the relatively large amount of time, effort and persistence that they have invested in terms of the effect they feel they have had. I believe that the important task of strengthening communications between the 